\title{
STUDENTS' METACOGNITION PROCESS IN SOLVING MATHEMATICAL PROBLEMS IN TERMS OF KEIRSEY'S PERSONALITY TYPE
}

\author{
Intan Fathimah Ahmadah ${ }^{1}$, Rooselyna Ekawati ${ }^{2}$ \\ ${ }_{1,2}$ Universitas Negeri Surabaya \\ e-mail: $\underline{\text { 1intanahmadah@gmail.com, }}$ 'rooselynaekawati@unesa.ac.id
}

\begin{abstract}
Abstrak
Metakognisi memainkan peran penting dalam kegiatan pemecahan masalah. Ini akan membantu siswa menemukan apa masalahnya dan memahami bagaimana mendapatkan solusinya. Penelitian ini bertujuan untuk mendeskripsikan proses metakognisi siswa berdasarkan tipe kepribadian Keirsey. Penelitian ini menggunakan metode kualitatif dengan pendekatan deskriptif dan dilakukan dengan melibatkan delapan siswa yang memiliki kemampuan matematika setara dan jenis kelamin yang sama. Siswa terpilih mewakili tipe kepribadian Keirsey. Mereka akan melalui dua jenis tes, yaitu Keirsey Temperament Sorter dan Tes Kemampuan Matematika. Hasil penelitian menunjukkan bahwa setiap tipe kepribadian dapat melalui indikator proses metakognisi. Namun, ada beberapa komponen indikator yang terlewat. Siswa rational dan idealist belum mampu melakukan proses metakognisi pada tahap regulasi dengan baik. Siswa guardian dan artisan sudah mampu menjalankan proses metakognisi dengan baik. Penelitian ini menyarankan agar guru dapat memfasilitasi siswa dalam setiap tipe kepribadian dengan menentukan model pembelajaran, kegiatan pembelajaran, dan penilaian yang sesuai untuk memperoleh hasil yang lebih baik.
\end{abstract}

Kata kunci: Metakognisi, Pemecahan Masalah, Tipe Kepribadian Keirsey

\begin{abstract}
Metacognition plays an important role in problem-solving activities. It will help students to find what the problem is and understand how to get the solution. This study aimed at describing the student's metacognition process based on Keirsey's personality types. This research used qualitative method with descriptive approach and it was conducted involving eight students who have equal mathematical abilities and the same gender. The selected students represented Keirsey's personality types. They were carried out through two types of tests, namely the Keirsey Temperament Sorter and the Mathematics Ability Test. The result showed that each personality type could through indicators of the metacognition process. However, there are some indicator components missed. Rational and idealist student have not been able to carry out the metacognition process in the regulation stage properly. Guardian and artisan student have been able to carry out the metacognition process well. This study suggests the teacher can facilitate students in each personality type by determining the appropriate learning model, learning activities, and assessments to obtain better results.
\end{abstract}

Keywords: Metacognition, Problem Solving, Keirsey Personality Type

\section{Introduction}

Problem-solving is one of the essential mathematical learning. Based on Indonesia's national curriculum, students are required to be able to develop their mathematical problemsolving skills [1]. When students can solve problems, they can use any approach they can think of, use every piece of knowledge they have learned, and justify their ideas in ways they believe 
[2]. Students' success in solving problems is influenced by several factors, including gender [3], learning style [4], self-efficacy, and general mental ability [5]. There was another factor that affects the success of students in the process of solving mathematics problems, namely metacognition [6]. Metacognition is defined simply as "thinking about thinking" [7]. Metacognition plays an important role in problem solving activities. Metacognition in problem solving helps problem solvers recognize a problem that needs solving, find out what the problem is, and understand how to get a solution [8]. That statement accordance with [9] which states that metacognitive skills to ensure awareness and control in the problem solving process Furthermore, the direct effect of metacognition can be seen from research by [10],[11] student problem solving test scores were better obtained from students' better metacognition skills.

The Metacognition process has three components, there are awareness, evaluation, and regulation. As long as the metacognition process occurs, the activities that appear in each metacognition component are called metacognitive activity types. Awareness component in metacognitive activities include what students know, what students need to solve the problems, what students should do, where students are in the process of solving problems. Evaluation components include assessing results, assessing student difficulties, assessing progress, ability, or understanding. And regulation component includes strategy in planning, choosing strategy in problem solving, and formulation of goals[12].

Several studies have shown that students' metacognition was influenced by the type of personality [13], [14]. This is certainly possible because metacognition is related to the way a person thinks with their own thought. Personality influences a person in making decisions, causing the emergence of certain thoughts and behaviours [15], [16].

There have been a lot of ways to classify a person based on their personality type, one of them is the Keirsey personality type. Keirsey's personality type classifies people based on how a person obtained energy, obtained information, make a decision, and lifestyle [17]. Keirsey personality type classifies people into four personality types, there are guardian, artisan, rational, and idealist. The classification is based on Keirsey Temperament Sorter (KTS). This theory showcases how a person gains the energy (extrovert or introvert), how a person obtains information (sensing or intuitive), how a person makes a decision (thinking or feeling), and how the basic style of his life (judging or perceiving). Individuals with the Guardian type prefer to follow routine procedures with detailed instructions [18]. Or in other words, this type prefers class with traditional models with regular procedures. Individuals with the artisan type like classes with a lot of discussion and presentation because they tend to show their abilities, they like change and don't like stability. Individuals with the idealist type prefer to complete tasks by themselves than group discussions, like reading and writing, so that they are more suitable if given tests in descriptions or story questions. Individuals with rational types like explanations based on logic. This type likes teachers who not only explain the material but also explain the reasons and where the material comes from.

Several studies on students' ability to solve problems associated with personality type especially Keirsey' personality type have been conducted. The result was the different student personality types have different problem-solving processes [16], [19], [20]. Several studies on students' metacognitive abilities in solving problems have been carried out such as [6], [9], [21] these study shows a description of students' metacognition in solving problems. Based on these studies, there is limited research about students' metacognition process in solving mathematics problems based on personality types. Even though personality type is one component that is easily observed in class [22]. Based on the above explanation, this study aimed to describe students' metacognition process in solving mathematical problems based on Keirsey personality types. 


\section{Method}

\subsection{Sample of Research}

The research subject were selected from 62 Senior High School students $11^{\text {th }}$ grade in Gresik with different gender, mathematics ability and communication skills. Furthermore, they have selected with several tests to get the expected research subjects. The first test was Keirsey Temperament Sorter (KTS), the result of KTS was students grouped into four groups with different Keirsey Personality Types. The second test was Mathematics Ability Test (MAT), the result of MAT was the students' mathematical abilities were known, each group of Keirsey personality types divided into two group based on their mathematical abilities.

Based on these two tests, four research subjects were selected for each personality type with equal mathematics ability and same gender. Selected students who have high mathematical abilities, so that they can solve the problems given. Mathematics teacher also helped in found research subjects with good communication skills.

\subsection{Instrument and Procedure}

Data were obtained from the results of problem-solving tests (PST) carried out by each research subject and the results of interviews. PST consist of 2 essay question that research subject has to do. The problem given to students can be seen in figure 1.

1. Mr. Tono wants to start becoming a livestock farmer. He has a stable which he has can only accommodate 18 cattle. This year Pak Tono has IDR 420.000.000,00 and plans to buy a cow for IDR $21,000,000.00$ and a buffalo for IDR $14.000 .000,00$ and plans to sell it next year at a price of IDR 23.000.000,00 for cows and IDR 15.500.000,00 for buffalo. After buying livestock, Mr. Tono wants to register at the KUD Livestock in his village. However, to register, Mr. Tono must be able to show predictions that in 1 year, the maximum profit earned is at least $10 \%$ of the initial capital. Please indicate whether $\mathrm{Mr}$ Tono can register or not.

2. A textile craft house produces two types of products, namely blankets and bedsheets. In one week, the textile craft house can produce at least 200 blankets and at most 300 blankets, while for bed linen, the craft house can produce at least 300 sheets. In one week, the industry can make 800 blankets and bedsheets. The selling price for one blanket is IDR 250,000 , and one sheet is IDR 150,000 . To maintain its business, the textile craft house must meet the maximum profit target of IDR 700,000,000 or more in one month. Describe your explanation, whether the textile home can survive or not

Figure 1. The problem given to research subject

In the next day, the interview was carried out with the research subject to confirm their answers and obtained the stages of the metacognition process that could not be analysed from the research subject's answers. For the entire metacognition process to be confirmed, the interviewed protocol was compiled in Table 1 .

\begin{tabular}{|c|c|c|}
\hline $\begin{array}{l}\text { Metacognition } \\
\text { Process }\end{array}$ & $\begin{array}{l}\text { Metacognition Process } \\
\text { Indicator }\end{array}$ & Sample Question \\
\hline \multirow[t]{3}{*}{ Awareness } & $\begin{array}{l}\text { understand the } \\
\text { problem given }\end{array}$ & $\begin{array}{l}\text { What do you understand about the problem } \\
\text { given? } \\
\text { Now, Try to reread the problems given, do } \\
\text { you think your understanding is correct? } \\
\text { How do you understand it? }\end{array}$ \\
\hline & $\begin{array}{l}\text { - understand what is } \\
\text { asked by the problem }\end{array}$ & What does the problem ask? \\
\hline & $\begin{array}{l}\text { Rethink about the } \\
\text { problems given and }\end{array}$ & $\begin{array}{l}\text { What is the first time you do after } \\
\text { understanding the problem given? }\end{array}$ \\
\hline
\end{tabular}


matching them with similar problems that have been found and solved before

- Rethink previous unsolved problems

- Know the strategies that can be used to solve the problem given

Regulation

Evaluation

- Be aware of limitations (knowledge and strategy) in doing something

solve the given problem

- Repeatedly check the answers before making a decision

- make decisions about the effectiveness of the strategies to be used

- Rethink the sequence of strategic steps it used
Do you think of other similar problems that you have worked on before?

Why did you do that?

How is that other problem?

Do you also think about other similar problems that you have never worked?

What is the shape of the other problem?

Where did you find that question?

After thinking about similar questions, have you been able to determine what strategy you will use in solving these problems afterwards?

What strategy will you use in solving the problem?

Why are you sure the strategy you chose was appropriate to solve the problem that was requested?

Why did you choose to use this strategy?

Do you also think about your reasons for choosing that strategy when solving the problem?

Have you ever thought about using other strategies to solve that problem?

Every time you want to continue work, do you check your previous work is correct or not, then continue your work?

Do you think that the strategy you are using has been effective or not?

Of the several strategies that you can use to solve this problem, why do you think the strategy you chose has been effective?

When working with the strategy you chose, did you think the sequence of the steps you took was correct or not?

Why did you do that?

After working on the questions with the strategy you chose earlier, did you doublecheck the answers you got?

Are you sure the results you got have answered the questions given?

After working on these problems, do you realize that you have limitations in doing something?

For example, the method I use is correct with the knowledge and strategies I have

\section{Result and Discussion}

Data explanation was conducted based on eight research subjects. They were two rational students (RS), two idealist students (IS), two guardian students (GS) and two artisan students 
(AS). The next step was to study eight students' metacognition process was carried out through the component indicator of awareness, regulation, and evaluation.

- Awareness had 5 component of indicator. They were the subject understands the problem given (A1), knows what is asked by the problem (A2), Rethink about the problems given and matching them with similar problems that have been found and solved before (A3), Rethink previously unsolved problems (A4), Know the strategies that can be used to solve the problem given (A5).

Regulation had 4 component of indicator. They were the subject choose the strategy that will be used in solving the problem (R1), Rethink the reasons for using the chosen strategy (R2), Think of other ways to solve the given problem (R3), Checking repeated answers before making a decision (R4).

Evaluation had 4 component of indicator. They were the subject can make decisions about the effectiveness of the strategies to be used (E1), Rethink the sequence of strategic steps used (E2), recheck the results (E3), Be aware of limitations (knowledge and strategy) in doing something (E4).

\subsection{Metacognitive Process of Rational Student}

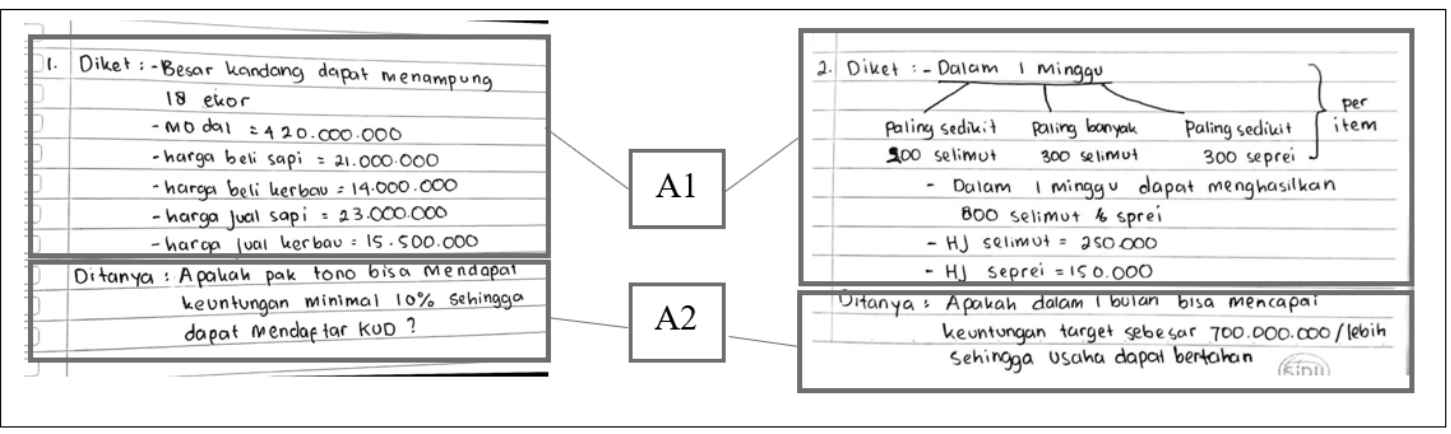

Figure 2. RS1's Answer Sheet

Based on Figure 2, it can be seen that RS1 doing two components of awareness, there are A1 and A2. Then, the interview was conducted to find out what RS1 was doing next. From the interview results, it was found that RS1 did not carry out components A3 and A4 because according to RS1's opinion, RS1 had never encountered a similar problem to the problem given. Although not through A3 and A4 components, RS1 can find out how to solve a given problem (A5). According to RS, these problems can be solved with a linear program because RS1 must seek the greatest profit. In other words, RS1 uses logic in choosing strategies to solve problems. This is in line with the statement which states that students with rational personality types like something based on logic in doing something [18].

Then RS1 solves the problems given with the chosen strategy, linear program with corner point test (R1), RS1 believes that the strategy chosen was right to solve the given problem. RS1 does not through the component of Regulation R2 because RS1 was sure that the problem could be solved with the chosen strategy. RS1's belief had an effect on R3 because RS1 was sure with the strategy that has been chosen, RS1 did not try to find other strategies to solve the problem. RS1 does not through the R4 component also. RS1 did not check the steps repeatedly when solving the problem because it was a waste of time. This is consistent with the statement that the rational personality type tends to ignore things that they think are not important and waste time [18].

RS1 can assess the effectiveness of the strategies used (E1). According to RS1, the strategy chosen was effective, RS1 also sure about it correctness. This is in line with Keirsey's statement which states that the Rational personality type will choose the most effective strategy for them [23]. Then RS1 checked the answers she gets (E3), if the answer she gets has solved the problem given and makes sense, then she assumed the answer was correct. The assumption 
was based on her awareness of the limited knowledge she has when solving the problem. In other words, RS1 realizes the limitations she has in solving problems (E4). RS1 did not through E2 component because she was sure of the step she remembered if she did the E2 component she felt that it would take a lot of time.

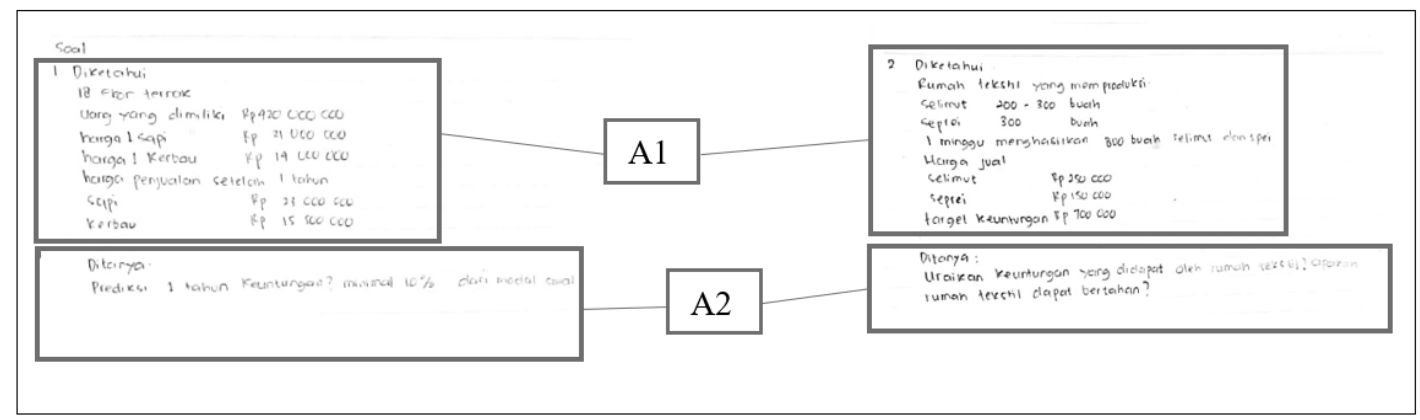

Figure 3. RS2's Answer Sheet

Based on Figure 3, it can be seen that RS2 did two components of awareness, there are A1 and A2. Then, the interview was conducted to find what RS2 was doing next. Based on the interview results, it was found that RS2 did the A3 component next. She did it to help her selected strategies that can be used to solve problems. She did not do the A4 component. According to RS2, the A4 component did not really help her find the strategies to solve the given problem. This is in line with Statement that the rational personality type tends to ignore things that they think are not important and waste time [18]. Although not through A4 components, RS2 can find strategies to solve the given problems (A5). According to RS2, these problems can be solved using a linear program with a corner point test or iso profit line because RS2 must seek the greatest profit. In other words, RS2 uses logic and her memory to found the strategies. This is in line with the statement that students with rational personality types like something based on logic in doing something [18].

Furthermore, RS2 solves the problems given with the chosen strategy, linear program with iso profit line (R1), RS2 believes that the strategy chosen was right to solve the given problem. RS2 does not through the R2 component because RS2 was sure that the problem could be solved with the chosen strategy. Her belief affected R3 because RS2 was sure of the strategy that has been chosen. RS2 did not try to find other strategies to solve the problem. RS2 does not through the R4 component also. RS2 did not check the steps repeatedly when solving the problem because it was a waste of time. This is in line with statement that the rational personality type tends to ignore things that they think are not important and waste time [18].

RS2 can assess the effectiveness of the strategies used (E1). According to RS2, the strategy chosen was effective. RS2 was also sure about its correctness. This is in line with Keirsey's statement in [23], which states that the Rational personality type will choose the most effective strategy for them. Then RS2 checked the answers she gets (E3). If the answer she gets has solved the problem and makes sense, she assumed the answer was correct. The assumption was based on her awareness of the limited knowledge she has when solving the problem. In other words, RS2 realizes the limitations she has in solving problems (E4). RS2 did not through the E2 component because she usually did not check every step she has done. 


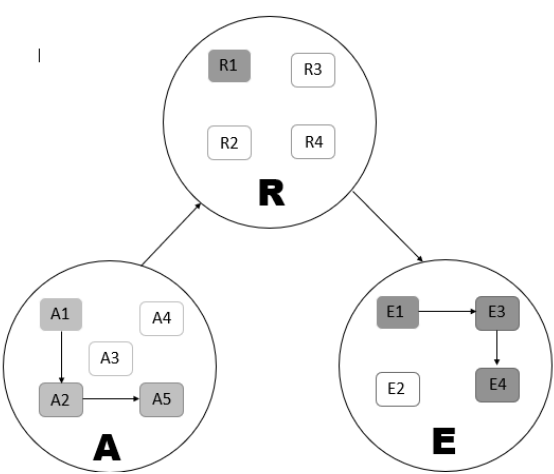

Figure 4. RS1 Metacognitive Process

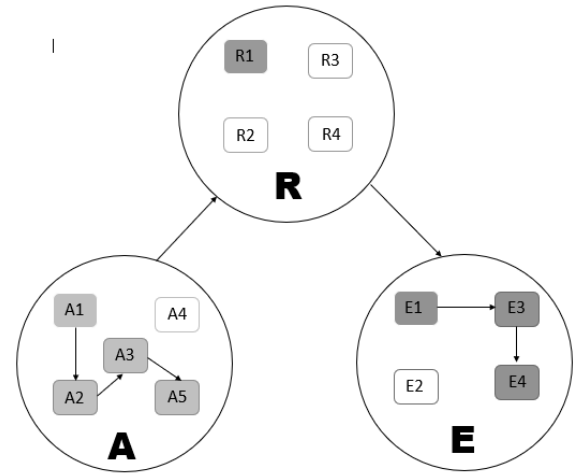

Figure 5. RS2 Metacognitive Process

\subsection{Metacognitive Process of Artisan Student}

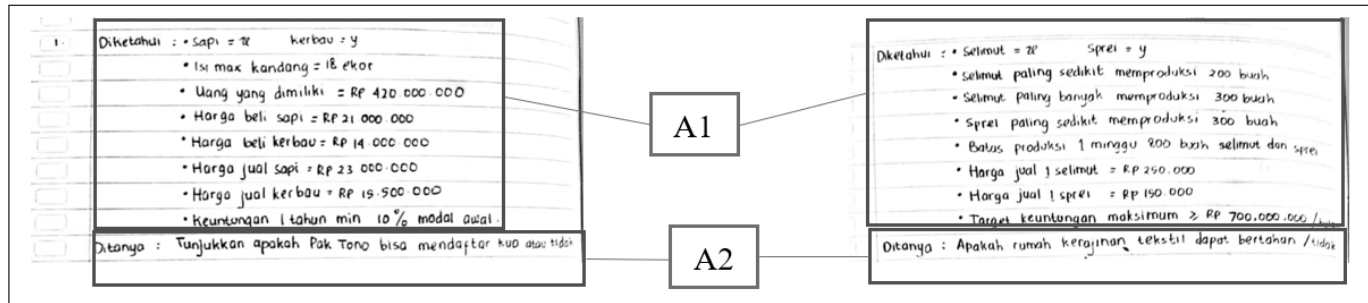

Figure 6. AS1's Answer Sheet

Based on figure 6, it can be seen that AS1 did A1 and A2. From the results of the interview, it was found that AS1's next step was to think about a similar problem (A3). She remembers that the problem given was similar to the assignment she was given in an online class. However, AS1 did not through the A4 component. According to AS1, the assignments she had done for online classes were enough to help her find strategies to solve a given problem. Based on a similar problem, AS1 knows how to solve a given problem, there are using a linear program with the corner point test or iso profit line (A5).

Then, AS1's next step was to try to find other strategies that she thinks can solve the problem faster (R3). AS1's actions are in accordance with the description of the Artisan personality type from [18], which states that people with the Artisan personality type like change and new things. AS1 tried to use a description strategy by linking every known information and trying to find solutions from that information. This is in line with statement that the Artisan personality type is a concrete communicator who prefers words rather than symbols [17]. Consider another strategy carried out by AS1 in figure 7. 


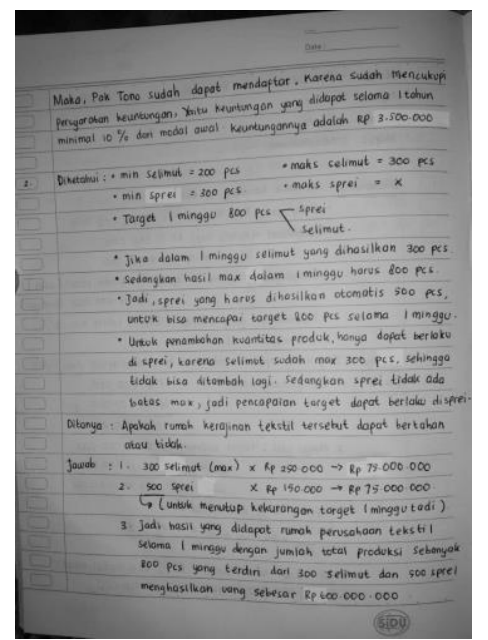

Figure 7. AS1's Another strategies for $2^{\text {nd }}$ problems

The results she got did not make sense, so she decided to use a linear program with the corner point test (R1). AS1 chose to use the corner point test strategy because she understood the strategy better than the iso profit line (R2). Furthermore, when she was solving the problem, AS1 claimed she checked the results many times before continuing her work (R4). AS1 did this repeatedly until she got a solution to the problem.

After getting a solution, AS1 crosschecked all stages of the strategy she worked on, including the sequence of steps (E2). Then AS1 checks the solution she gets and matches the problem given. AS1 does this to ensure that she has solved the problem given. Then, AS1 checks the solution she gets and matches the problem given. She does that to ensure that she has solving the problem (E3). After AS1 rechecks the solution to the problems obtained by AS1, she assessed that the strategy was not effective when viewed from the number problem solving processes that were carried out (E1). After solving the problem as a whole, AS1 also realized the limited knowledge of solving the problems he had at that time (E4).

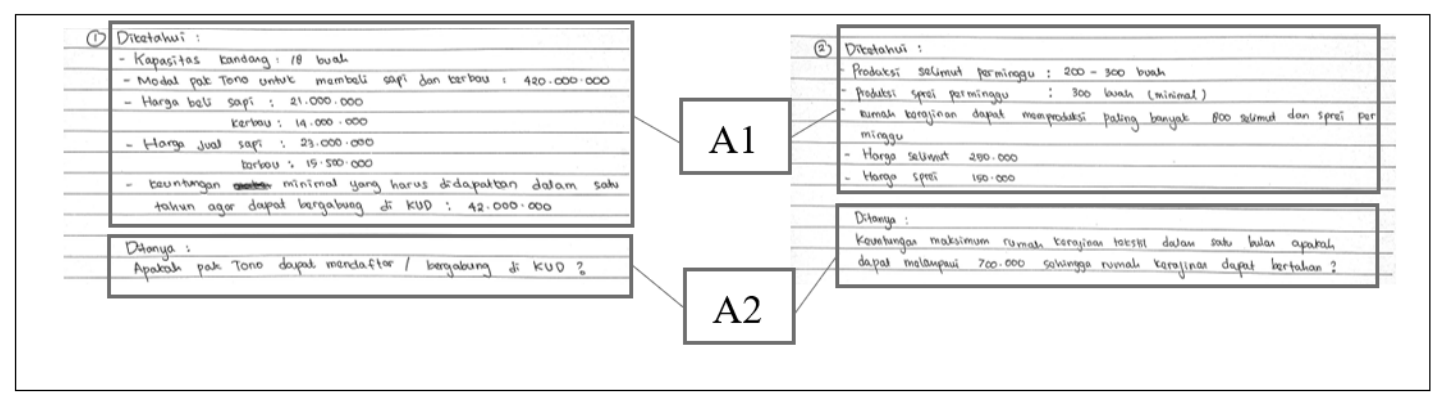

Figure 8. AS2's Answer Sheet

Based on figure 8, it can be seen that AS2 did A1 and A2. From the interview results, it was found that AS2's next step was to think about similar problems (A3). She remembers that the problem given was similar to the assignment she was given in an online class. However, AS2 didn't think of a similar problem that had never been solved (A4). According to AS2, the assignments she had done for online classes were enough to help her find strategies to solve a given problem. Based on the A3 component, AS2 knows how to solve a given problem (A5), there are using the linear program with the corner point test or iso profit line.

Then, AS2's next step was to try to find other strategies that she thinks can solve the problem faster (R3). AS2's actions is in line with the description of the Artisan personality type by from [18], which states that people with the Artisan personality type like change and new things. Consider another strategy carried out by AS2 in figure 9. 


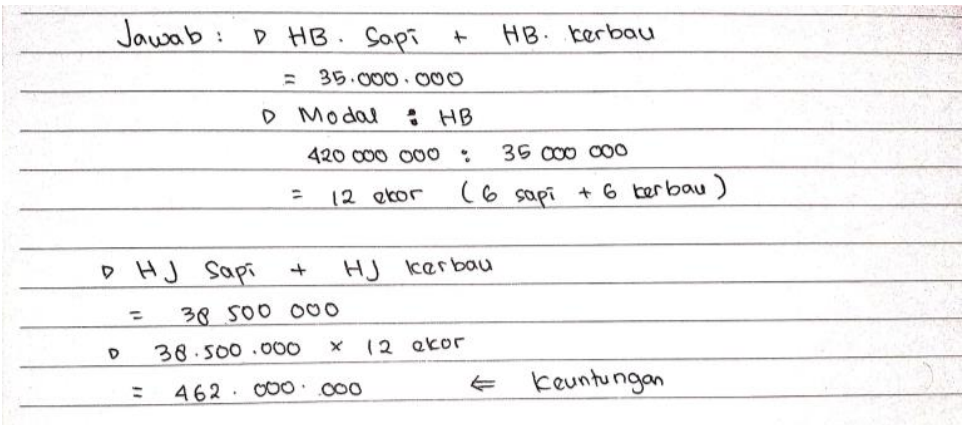

Figure 9. AS2's Another strategies

AS2 tried to use a description strategy by linking every known information and trying to find solutions from that information. This is in line with the statement from [17] that the Artisan personality type is a concrete communicator who prefers words rather than symbols. But, the results she got did not make sense for her, so she decided to use a linear program with the iso profit line (R1). AS2 chose to use the iso profit line strategy because she thinks the strategy steps are shorter than the corner point test (R2). Furthermore, when she was solving the problem, AS2 claimed she checked her result many times before continuing her work (R4). AS2 did this repeatedly until she got solutions of the problem.

After getting a solution, AS2 crosschecked all stages of the strategy she worked on, including the sequence of steps (E2). After AS2 recheck the steps of the strategy, she assessed that the strategy was effective for her to solve the problem (E1). Then AS2 checks the solution she gets and matches the problem given. AS2 does this to ensure that she has solved the problem given. Then, AS2 checks the solution she gets and matches the problem given. She does that to ensure that she has solving the problem (E3). After solving all the problems, AS2 realized the limited knowledge of solving the problems she had at that time (E4).

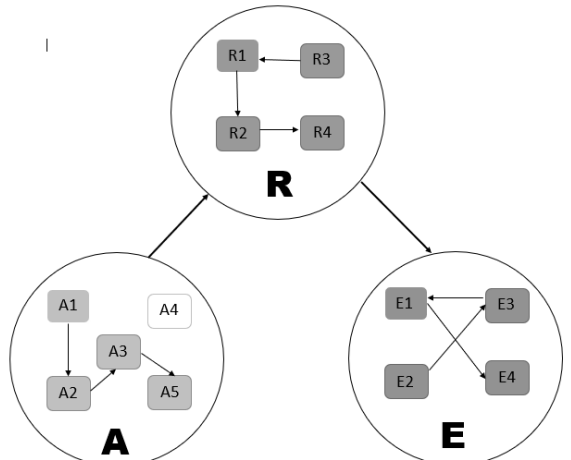

Figure 10. AS1 Metacognitive Process

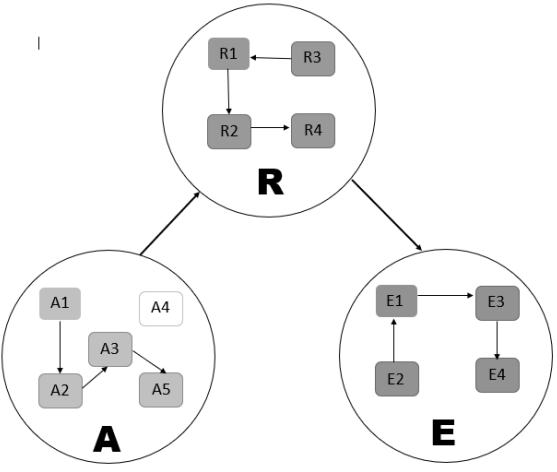

Figure 11. AS2 Metacognitive Process

\subsection{Metacognitive process of Guardian Student}

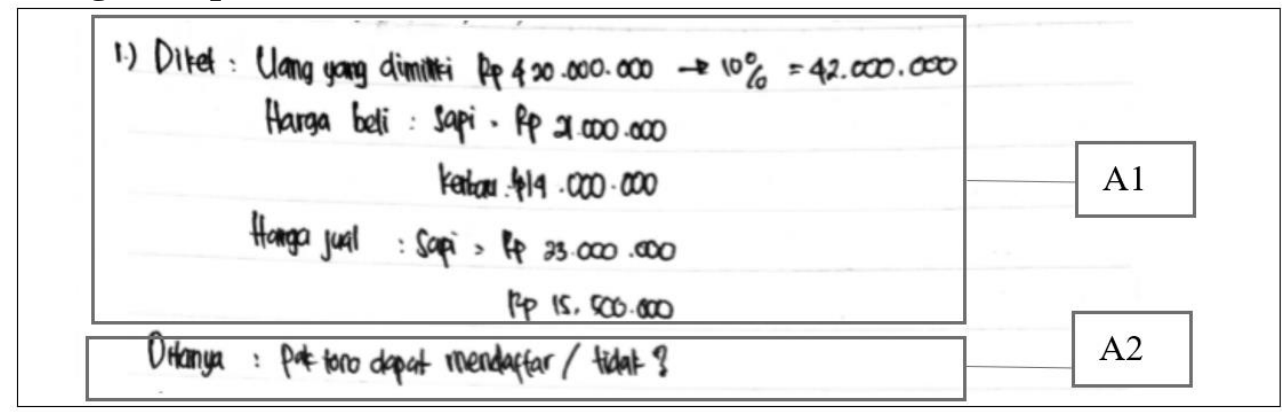

Figure 12. GS1's Answer Sheet 


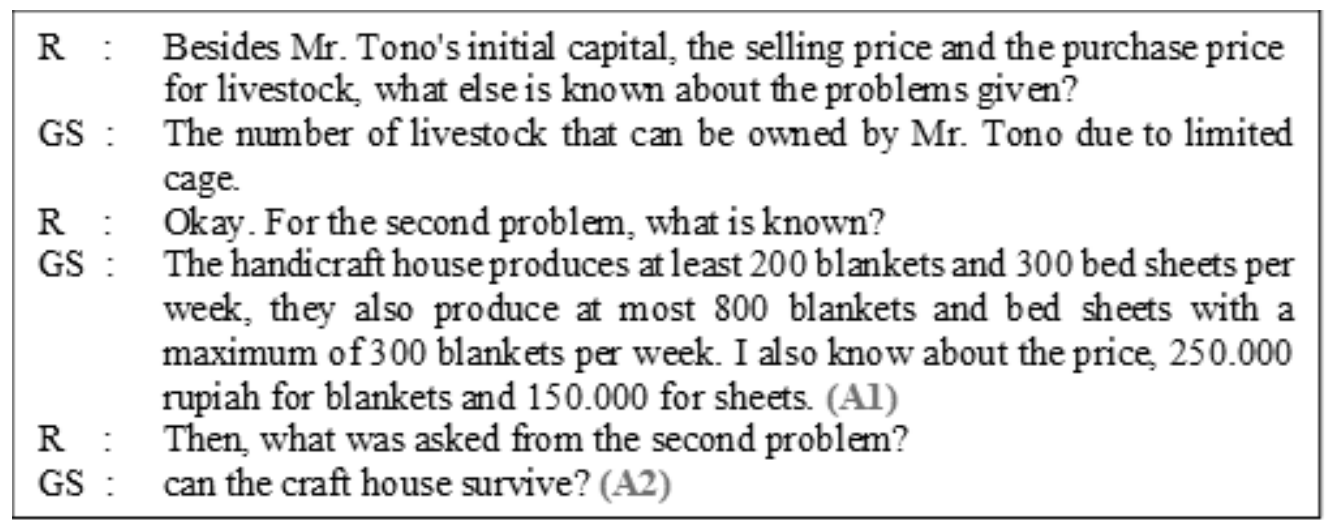

\section{Figure 13. Interviewed Script with GS1}

Based on Figures 12 and 13, GS1 did A1 and A2. From the interview results, it was found that GS1's next step was remembered the similar problems (A3). This is consistent with the statement from (Raza et al., 2014) that students with sensing personality types (including guardians) trust their experiences in solving similar problems. GS1 said she remembered a lot of problems similar to the problems given. This was consistent with the statement from Keirsey and Bates (1984) that the guardian personality type has a strong memory. So that she knew strategies that can be used to solve it, there are the corner point test or iso profit line (A5). GS1 also said that she did not through the A4 component because she thought that she had solved all of the similar problems.

Then, GS1 chose the strategy that will be used to solve the problem. She decided to use the corner point test (R1) because she understands the strategy better (R2). GS1 thought to use another strategy that she thought would shorten the processing time (R3), but she continued her worked with the strategy she had chosen from the beginning. GS1 does not repeatedly check her work while she was work (R4). Although she was worried, she continued to solve the problem based on her memory of the chosen strategy steps.

Then, GS1 through the E1 component, after finding the solutions, she argued that the strategy she chose was effective. GS1 also through E2 and E3 components consecutively to check the correctness of the solution she gets. After ensuring that the solution she got was correct, GS1 ended the problem solving by realizing the limitations she had (E4), especially regarding knowledge of strategies to solve problems.

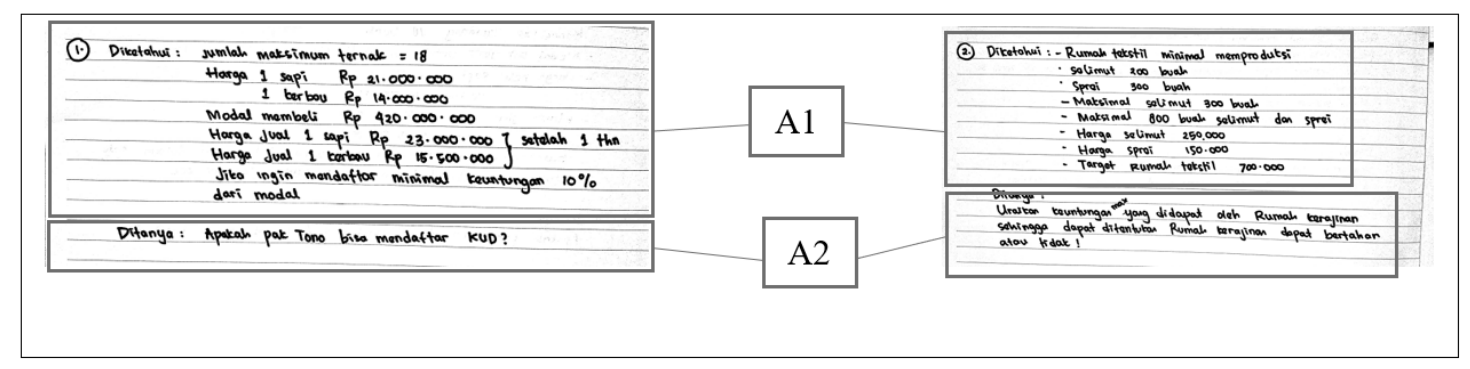

Figure 14. GS2's answer sheet

Based on figure 14, GS2 did A1 and A2. From the interview results, it was found that GS's next step was remembered the similar problems (A3). This is consistent with the statement from Raza et al. (2014) that students with sensing personality types (including guardians) trust their experiences in solving similar problems. GS2 said she remembered a lot of problems similar to the problems given. This was consistent with statement that the guardian personality 
type has a strong memory [18]. So that she knew strategies that can be used to solve it, there are the corner point test or iso profit line (A5). GS2 also tried to remember other problems in the sample questions in her student book (A4) to make sure that she has memorized all the strategies that could be used to solve the problem.

Then, GS2 chose the strategy that will be used to solve the problem. She decided to use the corner point test (R1) because she understands the strategy better (R2). GS2 did not try to find other strategies to solve the problem (R3). According to GS2, the two strategies she had remembered earlier could be used to solve the given problem. This is in line with statement that individuals with the Guardian personality type like regular procedures in solving problems. GS2 did not trough R4 because she believed she had followed all the steps of his chosen strategy [18].

Then, GS2 through the E1 component, after finding the solutions, she argued that the strategy she chose was effective (E1). GS2 also through E2 and E3 components in consecutively to check the correctness of the solution she gets. After making sure that the solution she got was correct, GS2 ended the problem solving by realizing the limitations she had (E4), especially regarding knowledge of strategies to solve problems.

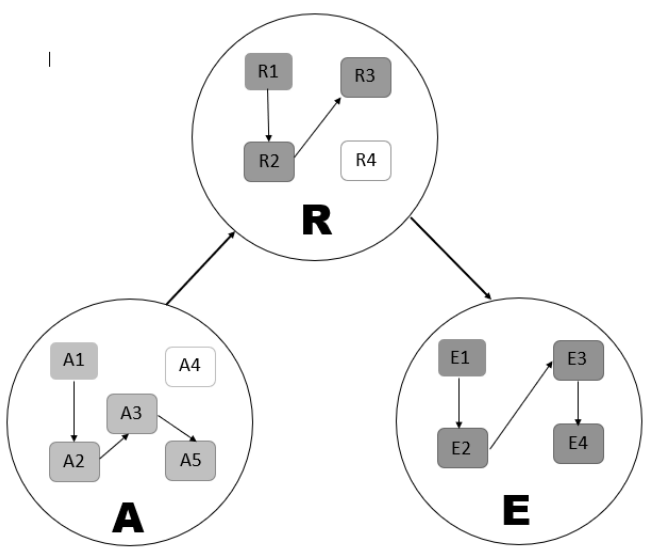

Figure 15. GS1 Metacognitive Process

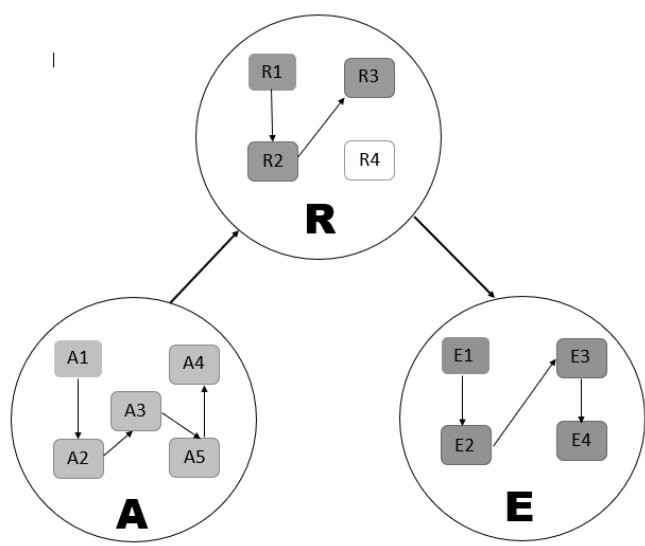

Figure 16. GS2 Metacognitive Process

\subsection{Metacognitive process of Idealist Student}

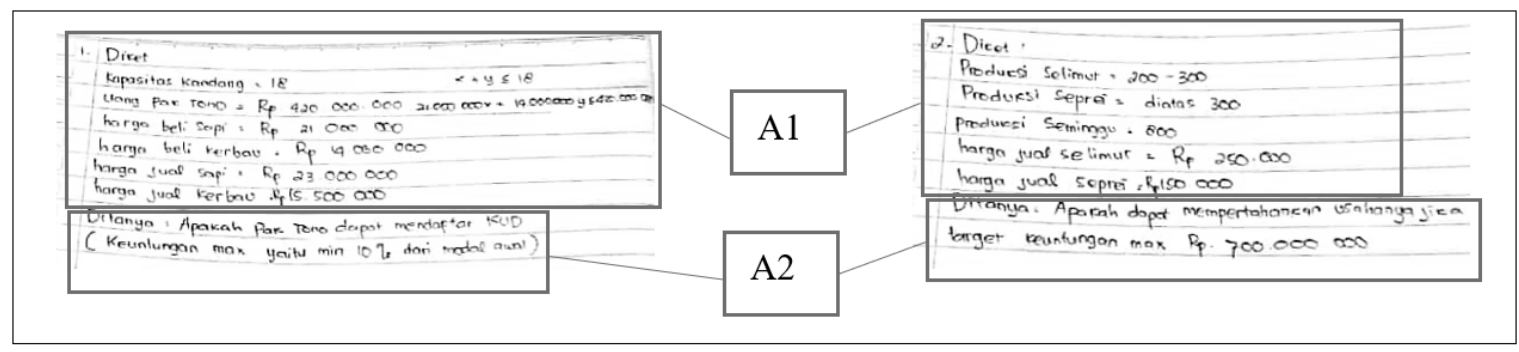

Figure 17. IS1's Answer sheet

Based on figure 17, it can be seen that IS1 did A1 and A2. IS analyzed each of the words contained in the problem given to understand it. Then IS1 remembered about problems that are similar to the problems given. The problem she remembered was the problems she had solved before (A3). She thought it could help her find how to solve the problem given. After the A3 component, IS1 can find strategies that can be used to solve the problem. There is linear program with iso profit line or corner point test (A5). IS1 found that strategies by connecting what is known, what is asked, and the knowledge she got from A3. This is in line with the research results that the idealist personality type connects what is known and asked to find out 
strategies in solving problems [25]. IS1 does not through the A4 component because she did not mind doing it.

Then, IS1 through the R1 component, she chose the corner point test strategy to solve the given problem. Furthermore, IS1 through R2 component, according to IS, the problem given can be solved appropriately by using the corner point test. IS1 did not through R3 and R4 components. IS1 states that after choosing the strategy and thinking about the reasons, she immediately works based on the strategy's steps. This is in line with the results of research from that the idealist personality type fast in action [25].

Furthermore, IS1 through E1 component, according to IS1, the strategy she chose was less effective in solving the problems given. IS1 did not through the E2 component because she trusted her memory about the strategic steps she had chosen. IS also did not through the E3 component. She admitted that she rarely checks the solutions she gets for the essay question. After got all the solutions, IS1 realizes her limited knowledge about strategies (E4).

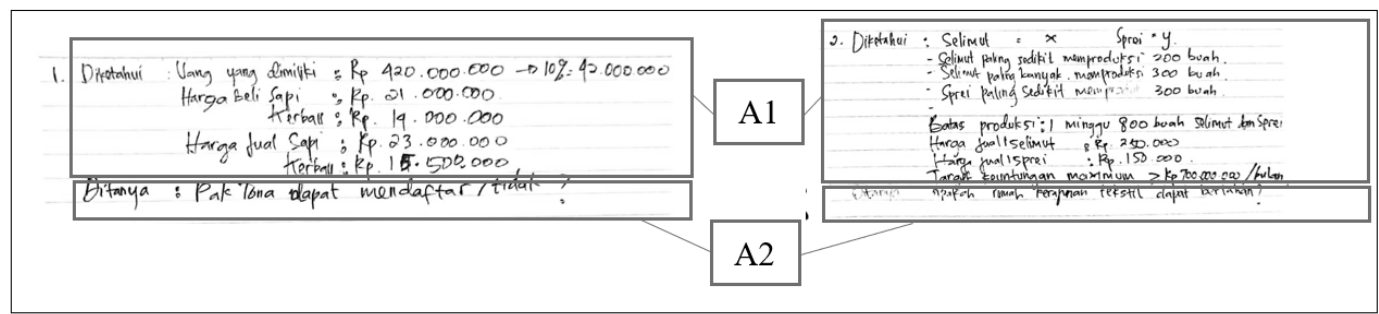

Figure 18. IS2's Answer sheet

Based on figure 18, it can be seen that IS2 did A1 and A2. IS2 analyzed each of the words contained in the problem given to understand it. Then IS2 remembers about problems that are similar to the problems given. The problem she remembered was the problems she had solved before (A3). She thinks it can help her find how to solve the problem given. After through the A3 component, IS2 can find the strategies that can be used to solve the problem. There is linear program with iso profit line or corner point test (A5). IS does not through A4 component because she did not think about doing that. For IS2, think about a solved problem would be more helpful for finding and choosing a strategy than thinking about the unsolved problem.

Then, IS2 through the R1 component, she chose the corner point test strategy to solve the given problem. Furthermore, IS2 through R2 component. According to IS, the problem given can be solved appropriately by using the corner point test. IS2 did not through R3 and R4 components. IS2 states that after choosing the strategy and thinking about the reasons, she immediately works based on the strategy's steps. For her, after rethinking the reasons for choosing a strategy, it is better to start solving the problem immediately because IS2 realizes that this problem has a long working stage. This is in line with the research results that the idealist personality type fast in action [25].

Furthermore, IS2 through E1 component, according to IS2, the strategy she chose was less effective in solving the problems given. IS2 did not through the E2 component because she trusts her memory about the strategic steps she had chosen. IS2 also did not through the E3 component because he was sure of the answer he got. This is in line with the research results from that students with idealist personality types were sure of the answers they get [26]. After got all the solutions, IS2 realizes her limited knowledge about strategies (E4) . 


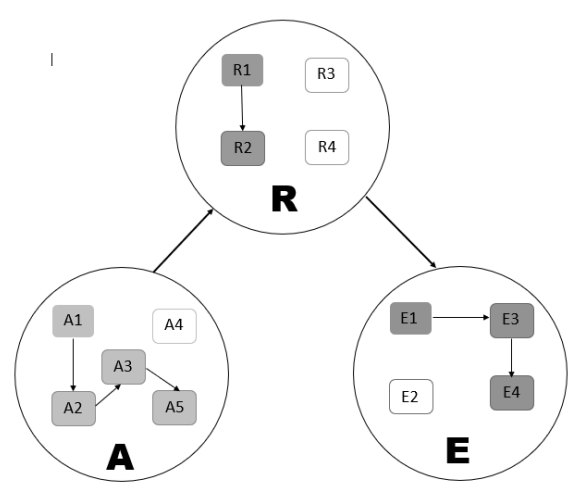

Figure 19. IS1 Metacognitive Process

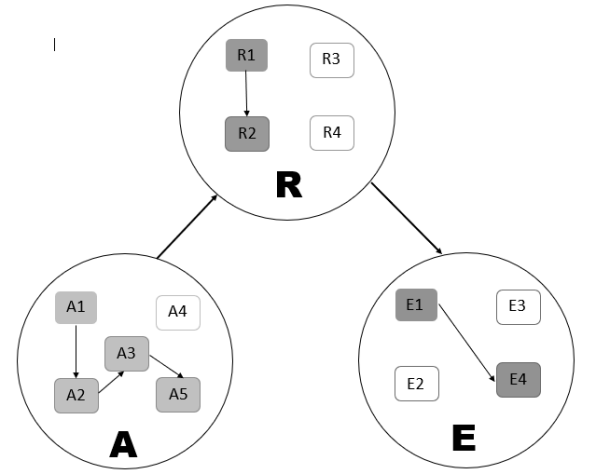

Figure 20. IS1 Metacognitive Process

\section{Conclusion}

Based on the results and discussion above, it is known that each Keirsey personality type has through all metacognition process indicators. Students with the rational personality type can through the awareness stage, although not through all of its components. The component that was passed by the rational student was thinking about problems that have never been solved. For the regulation stage, they only choose the strategy to be used component. At this stage, it can be seen that the rational subject does not really use its metacognition. Rational students also pass through almost all evaluation stages except rethinking about the order in the strategy's step they use. So it can be concluded that rational students have not been able to properly carry out the metacognition process, especially in the regulation stage.

Students with the artisan personality type can through the awareness stage, although not through all of its components. The component that is passed by artisan students was thinking about problems that have never been solved. For the regulation stage, artisan students can through all regulation components. Artisan students also pass all evaluation components. It can be concluded that artisan students have been able to carry out the metacognition process well.

Students with the Guardian personality type can through the awareness stage well. Even one research subject can through all the components at this stage. For the regulation stage, guardian students through almost all components of regulation. Components that do not pass are rechecking answers before making a decision. For the evaluation stage, guardian students can through all the components of that stage. So it can be concluded that the Guardian students have been able to carry out the metacognition process well.

Students with idealist personality types can through almost all components in the awareness stage. The component that is missed is thinking about problems that have not been solved before. For the regulation stage, idealist students only go through two components, namely choosing the strategy to be used and rethinking the reasons for choosing that strategy. For the evaluation stage, idealist students can go through all the components of that stage. It can be concluded that idealist students have not been able to carry out the metacognition process properly, especially in the regulation stage.

Based on the research results, The teacher should know the personality type of each student has so that it can be taken into consideration for determining the appropriate learning model, learning activities, and assessments to use. So teachers can facilitate students in each personality type to obtain better results. All students in each personality type can potentially solve a given problem if they can properly carry out the metacognitive process. However, students with a rational personality type need to be given special attention in the learning process to develop and explore the metacognitive process properly.

\section{Reference}

[1] Kemendikbud, Peraturan Menteri Pendidikan dan Kebudayaan tentang Implementasi Kurikulum. Jakarta: Kementrian Pendidikan dan Kebudayaan Republik Indonesia, 2013. 
[2] NCTM, "Why Is Teaching With Problem Solving Important to Student Learning?," no. 703, 2010.

[3] A. M. Gallagher et al., "Gender Differences in Advanced Mathematical Problem Solving," vol. 190, pp. 165-190, 2000, doi: 10.1006/jecp.1999.2532.

[4] L. Carmo, F. Pereira, A. Gomes, and A. Mendes, "Learning styles and problem solving strategies," in 3rd E-Learning Conference, 2006, no. September, pp. 7-8.

[5] F. Pajares and J. Kranzler, "Self-Efficacy Beliefs and General Mental Ability in Mathematical," Contemp. Educ. Psycology, vol. 20, pp. 426-443, 1995, doi: 10.1006/ceps.1995.1029.

[6] D. Setyadi, "Proses Metakognisi Mahasiswa Dalam Memecahkan Masalah Matematika ( Studi Kasus Pada Mahasiswa Pendidikan Matematika UKSW )," J. Mat. Kreat. - Inov., vol. 9, no. 1, pp. 93-99, 2018, doi: 10.15294/kreano.v9i1.13505.

[7] J. A. Livingston, "Metacognition : An Overview," 2003.

[8] A. Kuzle, "Patterns of Metacognitive Behavior During Mathematics Problem-Solving in a Dynamic Geometry Environment Ana Kuzle University of Paderborn," Int. Electron. J. Math. Educ., vol. 8, no. 1, pp. 20-40, 2007.

[9] S. Sengul and Y. Katranci, "Meta-cognitive Aspects of Solving Indefinite Integral Problems," Procedia - Soc. Behav. Sci., vol. 197, no. February, pp. 622-629, 2015, doi: 10.1016/j.sbspro.2015.07.205.

[10] R. Dewi, "Keterampilan Metakognitif Siswa dalam Menyelesaikan Permasalahan Pada Materi Larutan Penyangga Melalui Model Pembelajaran Pemecahan Masalah," Universitas Pendidikan Indonesia, 2014.

[11] L. Nulhakim, "Analisis Keterampilan Metakognitif Siswa yang Dikembangkan Melalui Pembelajaran Berbasis Masalah pada Materi Kelarutan dan Hasil Kali Kelarutan," Universitas Pendidikan Indonesia, Bandung, 2013.

[12] M. T. Magiera and J. S. Zawojewski, "Characterizations of social-based and self-based contexts associated with students'awareness, evaluation, and regulation of their thinking during small-group mathematical modeling," J. Res. Math. Educ., vol. 42, no. 5, pp. 486-520, 2011, doi: 10.5951/jresematheduc.42.5.0486.

[13] T. J. Batteson, R. Tormey, and T. D. Ritchie, "Approaches to learning, metacognition and personality ; an exploratory and confirmatory factor analysis," Procedia - Soc. Behav. Sci., vol. 116, pp. 2561-2567, 2014, doi: 10.1016/j.sbspro.2014.01.611.

[14] N. Soleimani, O. Nagahi, M. Nagahisarchoghaei, and R. M. Jaradat, "The Relationship between Personality Types and the Cognitive - Metacognitive Strategies," vol. 8, no. 2, pp. 29-44, 2018, doi: 10.5296/jse.v8i2.12767.

[15] N. Ibrahimoglu, I. Unaldi, M. Samancioglu, and M. Baglibel, "The Relationship Between Personality Traits And Learning Styles: A Cluster Analysis," Asian J. Manag. Sci. Educ., vol. 2, no. 3, pp. 93-108, 2013.

[16] Masriyah and M. H. Firmansyah, "Students' Mathematical Literacy in Solving PISA Problems Based on Keirsey Personality Theory," J. Phys. Conf. Ser., vol. 953, no. 1, 2018, doi: 10.1088/1742-6596/953/1/012203.

[17] D. Keirsey, Please Understand Me II: Temperament, Character, Intelligence. California: Prometheus Nemesis Books, 1998.

[18] D. Keirsey and M. Bates, Please Understand Me. California: Prometheus Nemesis Books, 1984.

[19] L. D. Fitriana, Y. Fuad, and A. H. Rosyidi, "Dynamism of Open-Ended Problem Solving: Study on Junior High School Students Behavior Based on Keirsey Personality Type," in International Conference on Science, Technology, Education, Arts, Culture 
and Humanity (STEACH 2018), 2018, vol. 277, pp. 1-5, doi: 10.2991/steach-18.2019.1.

[20] S. Solichah and R. Sulaiman, "the Profile of Junior High School Students About Pisa Problem Solving Based on Personality Type," MATHEdunesa, vol. 8, no. 3, pp. 465471, 2019.

[21] D. Purnomo, T. Nusantara, and S. Rahardjo, "The Characteristic of the Process of Students ' Metacognition in Solving Calculus Problems," Int. Educ. Stud., vol. 10, no. 5, pp. 13-25, 2017, doi: 10.5539/ies.v10n5p13.

[22] M. J. Dewiyani, "Karakteristik Proses Berpikir Siswa dalam Mempelajari Matematika Berbasis Tipe Kepribadian," in Prosiding Seminar Nasional Penelitian, Pendidikan dan Penerapan MIPA, 2009, pp. 481-492.

[23] A. D. Pertiwi, Masrukan, and B. E. Susilo, "Analisis Kemampuan Komunikasi Matematis Melalui Pembelajaran Model 4K Berdasarkan Tipe Kepribadian Peserta Didik Kelas VII," Kreano J. Mat. Kreat., vol. 5, no. 2, pp. 195-204, 2014, doi: 10.15294/kreano.v5i2.4550.

[24] A. Raza, L. F. Capretz, and Z. U. L. Mustafa, "Personality Profiles of Software Engineers and Their Software Quality Preferences," Int. J. Inf. Syst. Soc. Chang., vol. 5, no. 3, pp. 77-86, 2014, doi: 10.4018/ijissc.2014070106.

[25] Kasriana and R. Ode, "Deskripsi Kemampuan Pemecahan Masalah Trigonometri Ditinjau dari Tipe Kepribadian dan Tingkat Kecemasan Belajar Siswa kelas X SMA Negeri 6 Makassar," J. Mat. dan Pembelajaran, vol. 6, no. 2, pp. 158-171, 2018.

[26] I. Riawan and D. R. Puspananda, "Analisis kemampuan pemecahan masalah matematika pada materi aritmatika sosial ditinjau dari tipe kepribadian siswa," vol. 2, no. 20, pp. 1324,2020 